\title{
Millennium Challenges and Transformation of Natural Principles in Blake Morrison's And When Did You Last See Your Father? : A critical Approach
}

\author{
Alidou Razakou Ibourahima Boro
}

University of Parakou, Benin

Received: 14 Oct 2021; Received in revised form: 25 Nov 2021; Accepted: 05 Dec 2021; Available online: 18 Dec 2021 (C)2021 The Author(s). Published by Infogain Publication. This is an open access article under the CC BY license (https://creativecommons.org/licenses/by/4.0/).

\begin{abstract}
The main concern of this scientific paper isto make a thorough studyof unavoidablejuggernauts that torment English people, but balance the worldin the autobiographical and contemporary novel of Blake Morrison's And When did you last See Your Father?. In the course of the implementation, I, through a rigorous demonstration, indicate the trial that human beings must face through some conversions and current endeavous.Moreover, I display the impacts of technologies on human beings' state of mind in the twentieth century.To acquire those outcomes, I have applied to ourinvestigation Narrative Fiction, New Historicism and Critical Discourse Studies theories.
\end{abstract}

Keywords_Life ; Family; Principles;Change; Technologies.

Résumé-L'objectif principal de ce travail de recherche est de faireune étude approfondie sur la force irrésistible et inévitable qui tourment les anglais, mais qui équilible la vie dans le roman autobibliographique et contemporain de Blake Morrison qui s'intitule:And Whendidyou last SeeYourFather?.Dans l'exécution de cette étude, nous, àtravres une demonstration rigoureuseavons indiqué que les êtres humains font face à des situations dans certaines conditions trouvent les voies de sorties ou de se tirer d'affaires. En outre, nous avons exposé les impacts de la technologie et contraintes sociales sur l'état d'âme les êtres humains au vingtième siècle. Pour obtenir ces resultats, nous avons appliquéau cours nos investigations des theories telles que la Narration de Fiction, la Nouvelle Historicisme et Etudes sur Critique du Discours.

Mots Clés-Life, Famille, Principes, Transformation, Technologies.

\section{INTRODUCTION}

In his work entitled Exploring social life, James M. Henslin claimed:

All of us, at least to some degree, want to understand social life. If nothing else, we want to understand why people react to us as they do. We may want to know why some boast and tell lies, whereas others will undergo personal hardship to tell the truth.

To some extent his statement means that social flaws like civil rights, gender discrimination, lack of education, covetousness can be considered as consequences of the non-respect or ignorance of natural principles. Because around the world there are natural and non-natural principles or standars that people must respect. Among the natural ones, there are some that peoplelike timeuse

\footnotetext{
1James M. Henslin, Exploring Social Life, USA:

Pearson,2004, p. 1
} 
without distinction or add as additional resources because they want at all cost improve themselves. They even advocate the modification of what is legal to unreasonable.

In the light of those social issues, Blake Morrison wrote fictional novels related to social concerns and among those novels there is one that unveils and even reflects the twenties century life through the characters of this novel titled And When Did You Last See Your Father?In the respect of the century's social changes, this novel of Blake, through its characters depicts social shortcoming, unpleasing consequence of the lack of education marked by humiliation.In fact, And When Did You Last See Your Father? written in the twentieth century is about the issues that we encounter in the United Kingdom country and even around the world. People who are old but act as a very young one, those who are retired refuse to accept the administration decision by limiting their movement. People suffer of century's disease but live with animals and die after spending few days in painful conditions. In short Blake Morrison makes his audience live in live with him throughout the characters the novel And When Did You Last See Your Father? what our communities has become in the twentieth century in the matter of education, social change and obligation through security and excessive ambition.

The main objective of this paper is to highlight how the new technology through its giant means has impacted on men attitude toward women, animals under the twentieth heavy social burden. In social terms, our research paper unveils what British communities has become today in terms of dignity, trusworthy and sacrilege. In otherwords this is about how British people could despite their social burden rethinking significantly the promotion of the conservation the good mores, culture, children's education, the main members of the new British nuclear family, and then women empowerment. In order to deliver the set objective, this paper considers the qualitative method research to carry out a critical investigation, interpretation and criticism of Blake Morrison 's novel against the backdrop of three basic critical discourse studies theory - New Historicism and Narrative Fiction: Contemporary poetics.In terms of outline, we, first of all deal with the theoretical perspective and secondlybased on critical analysis we make the account of the official components of the British family. The third section bof this research paper is related to the drifts of while as natural thing in Blake's fiction and finally the last point has been concentrated on the ethics appraisal and the British people in Blake's fiction.

\section{THEORETICAL PERSPECTIVE}

In term of theoretical framework and through our tweaking, many theories have been listed to scan the understudy topic. However, the squeamishness of Blake's novel and the tenet of designing research work are two closed elements that conduct to the implementation of this paper.

First of all, we apply to And when did you last see your father?critical discourse studies theory for two reasons. The very first one is about type of the novel that we deal with. It is an autobiography novel or memoir in which Blake writes about himself and his family's concerned. Yet, self-presentation is one of the important section of critical discourse ${ }^{2}$ studies and throughout this theory,most speakers begin their speech with a selfpresentation that tends to focus ontheir various social identities. In addition, "Memoir" comes from the French word for memory. It's a literary genre of in which the author writes about his or her memories, usually going back to childhood ${ }^{3}$. So, the study process of the novel under study combines two important literary elements such as memoire and self-presentation which refer respectively to cognitive and first singular pronoun that are part of implementation of the book itself. For instance, through Critical discourse study, there are cognitive structures that are divided into three parts as followed memory or mind, mental models and Social cognition. ${ }^{4}$ Van Dijk ${ }^{5}$ ( 2014)'s theory completesGreenblatt (1982)'s new historicism in the matter of century ideology and era's implication of this research's enactment.

In fact, new historicism and human beings reactions, behaviours, disease and death depend on the period. The ins and outs of the findings based on this topic are hang on the issues of past and the present day. New historicism, is a literary theory which purposes to cognise or understand intellectual past through literature, and literature through its social context.

The type of Blake's novel, the generation of the writer and the attendance of the narrator himself in the book And when did you last see your father? entitle me the use of Narrative Fiction: Contemporary poetics. According to ShlomithRimmon-Kenan

\footnotetext{
${ }^{2}$ http://www.discourses.org/OldArticles/Critical\%20Discourse\%2 0Studies.pdf on September 10 ${ }^{\text {th }}, 2020$ at 17: 50

${ }^{3}$ https://literaryterms.net/memoir/ on September $10^{\text {th }}, 2020$ at 17: 54

${ }^{4}$ http://www.discourses.org/OldArticles/Critical\%20Discourse\%2 OStudies.pdf on September $10^{\text {th }}, 2020$ at 16: 15

${ }^{5}$ https://benjamins.com/catalog/z.184.79dij on September $10^{\text {th }}$ ,2020 at 12: 54
} 
In the third book of Plato's Republic Socrates posits a distinction between two ways of rendering speech: diegesis and mimesis. The characteristic feature of diegesis is that the poet himself is the speaker and does not even attempt to suggest to us that anyone but himself is speaking (1963, p.638). In mimesis, on the other hand, the poet tries to create the illustration that is not he who speaks. ${ }^{6}$

So, in terms of contemporary literary aspects and while allowing for the narrator presents himself and other, it seems compulsory to use Narrative Fiction: Contemporary poeticsin order to be well understood through my scientific paper. While allowing for all of the details related to the nature of the era throughout the century's stakes of the issue the novel understudy and its writer himself, to sum up, my investigation on Blake' $\mathrm{s}$ And when did you last see your father?rests on three literary theories.

\section{EXTENSION OF BRITISH FAMILY AND POPULATION}

As a matter of fact, the issue of companions and Blake's concept about people suit living conditions in the twentieth century and unveil the rebuilding of the British first social institution. According to the Webster's Beginning Dictionary, the word companion came from Latin that means "camrade". "Camrades can be brought as a people who share bread or eat together"7. Suppose that in Blake's family is a normal one as the others around the world and takes also British community realities into account, so there are members like children, mother and father and then there is no active actor as member of the family who can behave as human being, bring feeling and deserve care. Unfortunately, Blake declared: "Dog brought out sentimentalist to him." In the light of this kind of union of compassion and while interpreting the quotation "Gunner and Terry lasted all my childhood, and after their died my father did without dogs for a while, in homage", Unbelievably, by allowing for the highlight points related

\footnotetext{
${ }^{6}$ ShlomithRimmon-Kenan, Narrative Fiction:

Contemporary poetics, p.106

${ }^{7}$ Webster's Beginning Dictionary, P. 137

${ }^{8}$ Blake Morrison, And When Did You Last See Your Father?, p. 36

${ }^{99}$ Blake Morrison, And When Did You Last See Your Father?, p. 35
}

to love, friendship and sympathy, Blake's family has undergone slight transformation in the matter of number of members and feeling for others.I guess from this attitude of Blake's father that consist of taking care and feeling sympathy to animal that there is an additional member of the British family in Blake's fiction who is the dogs during the twentieth centrury. A dog is an animal that is often kept as pet or used to guard or hunt things. In British community during the twentieth century, dog is love and cannot be separated from people.This dog plays multiple and multiforme roles in British people's life through Blake Morrison's fiction. It even interests in the narrator and he goes so far saying "I reckon to win on the security question, pointing out as ungleefully as possible that Nikki had been in the house when it was burgled". In the matter of security challenge, the narrator pinpoints a contemporary concern which is related to the stealing. Today, the question still exists because we need an uncorrupted guard who can secure out offices and living and even goods and places. Even the policy makers advocate to the governments the use of dog's services to control their ports and airports so that to check drugs and other fraudulent goods .

The issue of security and household keeping become more and more important and then English people live with natural watcher. Man as watchman can be corrupted or can demand the involvement of many other investmentsand additional anxieties, peoplecan even be corrupted. The use person as watchman prevents British people from having an official private life in terms of work-life balance and freedom.Blake,despite his misunderstanding through some his grievances with his father to a certain extent, as a safety precaution invites the readers to make natural trail by adopting not only people in order to make peace in their living environment but also involve dogs in terms of security preservation.

The actors involving into the British householders over pass four types, Blake justifies such a thing by saying:

Sandra was Pat'spredecessor, the maid before. She ' $d$ come from a broken home in Scotland in 1963. I was thirteen. She was nineteen. My sister had just gone away to boarding-school. We were alone a lot, sharing the same teenage stuff -Titbits? Top of the Pops. She was young for her age after the traumas back home, and my father had felt protective, treated her as a 
daughter as much as an employee. ${ }^{10}$

For social fairness and be on the alert in the matter of precaution of contingency, the above statement of Blake rises three main points as followed: social collaboration, parenthood and household management. The issue of companion and parenthood cannot be denied. Because Sandra had been brought on the purpose to second Blake who became alone and the second one is about the assistance to people who is in dangerous situation and deserve care. But here Blake's fiction shows the love and Britishness hospitality since his father treated her as his own girl. Blake's father and like other British people, despite the fact that they limit the number of the birth and have just two children by avoiding social expenditures, they increase the number of the mouth to feed by bringing adoptedpeople as well as householder as employee. They even increase consciently the additional food of the dog which eats too much meat as meal and adopted girl as well. Arthur, Blake's as a retire one and despite his social burden increases his household expenditure in matter of mouth feeding, tightening of security of his living place without regard to his outcome in terms of salary or pension.

The audience of Blake and the worldwide generation need to feed themselves of the latest news and also know everything related to British family's stakes and how kind British people are. The novel of Blake reveals that there are more than three components of British family and its residents. It indicates the role of each one of them so that satisfy British people needs.

\section{DRIFTS OF WHILE IN BLAKE'S FICTION}

N'DeTanoDjaha in his article titled "LA MISE EN RECIT DU RÉEL A DRY WHITE SEASPON D'ANDRE BRINK" claimed that the issue of time indisputably revealed the structure of tale. Everything that had been happened at a given time, on a time and for a time ${ }^{11}$. In the light of my subject matter et while allowing for the contests imposed to the people of new generation, the time that Djaha talks about is different from what Blake is dealing with in his fiction despite the fact that he deals with fiction. Then, time has another part of definition which is not taken into account by N'DeTanoDjaha since through Blake's fiction's time,there

\footnotetext{
${ }^{10}$ Blake Morrison, And When Did You Last See Your Father?, p. 180

${ }^{11} N^{\prime}$ De Tano DHAHA, “LA MISE EN RECIT DU RÉEL A DRY WHITE SEASPON D'ANDRE BRINK",Multifontaines, V3, Janvier 2016, PP33-48.
}

is a multiple and multiform of questions regarding issue time in this novel written by the concerned person.

The state of being a parent, family leading and the concerns of morarility are worrying in Blake's fiction.The nature of the family and the wellbeing of its members vary widely from culture to culture and continent to continent around the world. In some societies, family members tend to stay in close proximity to their kins. Yet the narrator claimed: "My father has always love fast car and motorracing has a strong British following just now, which is why we are stuck in this country lane with hundreds of other cars" $" 12$. Then, there are issues concerning time, material good in terms of means of transport, the family good living conditions and public space usage. Arthur is fun of motor-racing because he was considered as a saver of time and he did not like waiting in queue. ${ }^{13}$ First of all, people are savers of something are dictators since they make every endeavour to save his interest throughout their covetousness. In the novel understudy,it said: "He is used to patients waiting in queues to see him." So the narrator explains what the Britishpeople become in the twentieth century in the matter of time and how across the while they make interest and profit. This means that Arthur, Blake's father makes profit of his time and make other called weak abuse of its because patients are sick people and at normal while they shall deserve a quickly care and assistance. Arthur is a dictator in the matter time saving. As "he is not used to waiting in queues himself." 14 To extent, the protagonist Arthur is implementing what the real British people undergo in the twentieth century since one person get two or more jobs and have to achieve his or her task a day. In those conditions their save time

Through the time efficiency, the novel of Blake depicts the women discrimination and empowerment of men in the matter of decision taking process. The narrator stated: "A queue, to him means a man being denied the right to be where he wants to be at a time of his own choosing, which is at the front, now ${ }^{15}$. Allowing for this claiming, for Arthur, woman has no right in the matter of time and man is free to where he wants to be at any time. Time efficiency has been the source of misunderstanding between Angel his wife, the mother of Blake and Arthur as his father, a doctor at hospital. Arthur as a time saver of while he is considered as a great dictator by using time as his own slave and act if he was God and can be omnipresent and omnipotent.Because of Arthur despises

\footnotetext{
${ }^{12}$ Blake Morrison, And When Did You Last See Your Father ?, p. 9 ${ }^{13} \mathrm{Ibid}, \mathrm{p} .13$

${ }^{14}$ Ibid, p. 9

${ }^{15}$ Ibid, p. 9
} 
her wife and imposed his decision regarding time saving. "Benjamin Franklin was America's scientist, inventor, politician, philanthropist and business man. He is best known as the only Founding Father who signed all three documents that freed America from Britain" ${ }^{16}$. In the light of this claiming related toBenjamin Franklin, the author of "time is money", Arthur as character of Blake's novel tries to implement this business man's ideology in British literaturein terms oftime efficiency. In this way, allowing for the background of Benjamin Franklin, Blake pinpoints in his fiction the importance of time and suggests to the new generation the new plan of time management. Arthur not only determines the notion of time through his feeling and desire but uses it as his own and makes of it a fiddle.

On the assumption that "time is money" lacks of additional and useful details.In fact, the squabble between the Arthur, Blake, his son because of time seems sound and even emphasises on the lack of details about time in British socio-economical contract.Time has created a lot of damages to Blake's parents to some extent. To begin with, time is a natural thing and no one can handle all in all its trend since the context is not clarified in the matter of road security, and even in natural disaster like diseases and health.First, in the light of the novel understudy title, When did you last see your father, of Blake Morrison and as far as Blake's father's habit is concerned, there are two elemental principles that caraterise Blake's father, the nature of time that is male and the kind of means of transport used to be on the focus of time or to the respect time keeping. For Blake's father, in the family, man must respect all thing concerning time. Reason why Blake emphasises on the argument between father and his mother who says why does he do this, why he cannot wait like everyone else ${ }^{17}$.Arthur, the father of Blake does not respect suggestions or advise made by his belove because of time. $\mathrm{He}$ also maltreats his children because of while. The narrator is complaining by stating that his sister and he were scrunched together as usual ${ }^{18}$. Through the title the novel the word "when" evoke time, the narrator claimed:"All those years of helping others with their golf club or pub dining-room extensions- projects quietly resented by my mother because time given to others was time denied to the family." 19 Whereas the main characters Blake and his father most of the time emphasise on time, so in the accordance of the topic understudy, time in $\mathrm{Mr}$. Morrison's novel is the unbreakable core in the socio-

\footnotetext{
${ }^{16}$ http://www.benjamin-franklin-history.org/benjaminfranklin/ on Saturday, 30th, 2021 at 9 AM

${ }^{17}$ Blake Morrison, And When Did You Last See Your Father ?, p.11

${ }^{18}$ Ibid, p. 10

${ }^{19}$ Ibid, p.44
}

economical contract of the British people. When we deny something, we state that it is not true. So, one of the elements related to British family contract breaching is time, people of Britain are abide by respecting timekeeping. Blake's uses the way the characters of his novel apprehend time to show his audience that the British socioeconomical contract is based on time efficiency and justifies that the native of the United States of America, Benjamin Franklin's assumption that says that time is money lack of additional and capital information related to the British family. Blake's fiction reveals that the notion of time management is from the homeland of English people and the one the United State of America is a fake one.

\section{ETHICS APPRAISAL AND THE BRITISH PEOPLE IN BLAKE'S FICTION}

The twentieth century's days, due to its social changes or shifts and its men's obligations throughout their permanent juggernaut in people life, there are tail-fin that most of the time do not necessarily depend on them since $a$ hungry man is an angry man. So, regarding the relationship between son and father, Blake has made some statements that deserve comments and analysis. If not, how can we understand "God Almighty, Arthur, why do you have to do this? Why can't you wait like everyone else? What if we meet something coming the other way? Now my sister and I do the same, hide ourselves below the seat" ${ }^{20}$. This claiming of the narrator, first of all proves that Arthur despites his wife and children'sgrievances and becausehe even has no consideration to them. This way of behaving witnesses silent war between father and other member of the familyand sounds the behavour of selfishness or narcissism. Secondly Arthur is a selfish man and his behavour of dictatorship prevent him from listening to the members of his family.

The selfish people are like a plague that compromises the remain ones regarding authoritarian because dictatorship, self-governing, self-importance, selfdefense and so on. Accordingly,all possible vices come. That is why Blake said: "I' $m$ happy to pay the difference ${ }^{21}$ ". Here Blake says indirectly what his father is, a corruptible one.Unfortunately, the steward is warming and had refused any briberies or anything corruptiblematerial things or corruption from Blake's father 's side regarding offence by just advising Arthur that henceforth check the colour his ticked and then took the right entrance. ${ }^{22}$ Considering the kinds of statement of And When Did You Last See Your Father?, the writer sounds

\footnotetext{
${ }^{20} \mathrm{Ibid}$, p. 11

${ }^{21}$ Ibid, p. 12

${ }^{22}$ Ibidp. 13
} 
evocative to some extent and it is compulsory regarding the role played by literature in today's life to measure morality's degree in Blake's fiction. It is possible to corrupt other administrative persons rather than this steward. However Blake's father is a corrupted one and even advocated to his citizens since charity begins at home. That is why at the twilight of Blake's childhood he has undergone the side effect of his father's bad behavour and his social juggernaut. Blake has been humbled and claimed: "My childhood was a web of little scams and triumphs." ${ }^{23}$ Here, Blake talks of the highlights of his life with his father. Most of the time, father has never used the right way to find solutions to his anxieties or disquiets. This statement of his own son Blake is the official source that proves that his father is a crook man and uses all ways to intimidate people. Arthur as character, is like a plague in British society since he tends to contaminate the trustworthy ones and starting from his own son. Blake himself tells the by protecting a little bit his daddy's personality and emphasises that his father had failed only once $^{24}$. Blake is also a liar as his father because "little triumphs" is opposite to "failed only once". Blake is right by being so because as son he must receive the education from his father and implement it in his life.

The novel of Mr. Morrison portrays the flaws of the twentieth century's people custom or behavour on the four lands of isles. This experience of life should be an example to right the attitude of the current ones because if the life is plenty of scams and swindlers the new generation can perish. The tangible example in Blake's fiction is the back of Sandra who had been maid of Arthur. "She ' $d$ married the boyfriend but the marriage hadn't lasted-only the son had, grown up now. Sandra stayed close to my parents ${ }^{25}$ ". Sandra's marriage does not last for two reasons. Because of her covetousness since her husband, Jeff ${ }^{26}$ was a carpenter and does have means to support her and their child but also her teenagerhood had been compromised through sexual underground of long time.

We went on having sex for six months, a year still she found a proper boyfriend and left. It was usually on Friday evening during term-time, when no one else was in the house, though we took our chances when we could.We'd be up in her bedroom, under the open widow, listen for the sound of my

\footnotetext{
${ }^{23}$ Blake Morrison, And When Did You Last See Your Father?, p. 14.

${ }^{24}$ Ibid, p. 14.

${ }^{25}$ Ibid,p. 180.

${ }^{26}$ Ibid, p. 182.
}

parents' car coming up the drive, the door slamming in the yard or the key in the front door. $^{27}$

In the light of the novel understudy and allowing for one of the keyword life ethics, the people of Blake have no good education as regard Spinoza in MémoRéférencesDictionnaire de Philosophie: ethics is a science that studies modes existence according to good and bad (my own translation) ${ }^{28}$. Following this definition of Spinoza, Blake's characters way of life is not a good one. Blake's behavour has been jeopardized by the one of his own father afterward compromised the one of maid of his father, Sandra, who has been for long secret girl friend of Blake himself, who is now complaint of his father' behavour.All in all, it is extremely regrettable that the words like scam, prostitution, lie, dictatorship, discrimination, selfishness, covetousness undermine the world built by Blake's fiction. At little difference, this is the way the member of the British community behaved in the twentieth cenyury.

\section{CONCLUSION}

Blake's fiction has through his characters focused on time that is as the progression of events from the past to the present into the future. In the process, the action of the charachers shows that no one can not maintain time. Basically, time is a natural thing and free gift from God and despite our state of mind, our concerns or emergency we can not make it stop since it is demension of reality use to describe event. Here, its saving, apart from its drawback like corruption, accident, has created marital conflit and even discrepancy between man and woman. Blake Morrison's fictional novel is one of the vivid one that unveil what sons cannot tell face to face to their fathers or daddies. Because sons must respect their parents in order to receive God blessing as it is mentioned in the holy Bible.And When Did You Last See Your Father?reveals social shortcoming in the matter of ethical issues and shows the different consequences through its characters that humiliation is the reward of bad education or dictatorship. In this light it clearly shows which kind of world is going to built and emphasises mainly of the British community through fiction. In Black fiction we have time to discover the sacrilege concerning people dignity. We also have time to know the consequences of covetousness in the matter of time saving, and money saving. We agree and have been confirmed that like father

\footnotetext{
${ }^{27}$ Ibid, p. 184.

28 Jacqueline Russ, Mémo Références Dictionnaire de Philosophie, P.97.
} 
like son, and we must pay attention to all we undertake in matter.

\section{REFERENCES}

[1] Morrison, Blake. And When Did You Last See Your Father?. Great Britain: Granta Books, 1998.

[2] Grooten, J. \&Steenbergen G. Jo. New Encyclopedia of Philosophy. New York : Philosophical Library, 1972.

[3] Henslin, M. James. Exploring Social Life, USA: Pearson, 2004

[4] Russ, Jacqueline. Mémo Références Dictionnaire de Philosophie. Paris :Bordas, 1991.

[5] Rimmon-Kenan, Shlomith. Narrative Fiction: Contemporary poetics.

[6] DHAHA, N'De Tano. "LA MISE EN RECIT DU RÉEL A DRY WHITE SEASPON D'ANDRE BRINK”, Multifontaines, Vol no 3, PP33-48.Janvier 2016. 